\title{
Specialty Cut Flower Production Guides for Florida: Sunflower 1
}

Rick Schoellhorn, Everett Emino and Erin Alvarez ${ }^{2}$

\section{Introduction}

\author{
Production guidelines for: Sunflower Cut \\ Flowers
}

Common Name: Sunflower

\section{Scientific Name: Helianthus annuus}

Family Name: Asteraceae

\section{General information about sunflowers:}

One of the four native American commercial crops of global importance, sunflowers are grown for oil seed, snack seed, birdseed, and garden flowers. In addition, they are now widely grown for cut flower production as a specialty cut flower. Sunflowers are drought tolerant, grow in full sun, and grow in a wide range of soil conditions as annuals and perennials. They are used in the landscape for borders, screening, or in containers. Many cultivars are available in colors that range from yellow to bronze, red, or cream. New cultivars have been introduced especially for bedding and cut flower use, as the familiar old cultivars and agronomic oil seed types are not well suited for these purposes. With proper cultivar selection, the flowering season in Florida is long and limited only by freezing temperatures. Many people are most familiar with the Russian Mammoth cultivar with its big seed head and tall, strong stems, which grow to ten feet high.

\section{Field Production}

\section{Soil}

pH preference: 6.5-7.5 and addition of composted organic matter is beneficial. Research results at UF/IFAS show faster crop time in soils amended with the addition of well-cured compost as well as benefits from enhanced soil properties such as improved cation exchange capacity of the soil.

\section{Light Levels}

Full sun

\section{Production Temperatures}

$72-86^{\circ} \mathrm{F}$ for growth, $46-50^{\circ} \mathrm{F}$ for germination

\section{Fertilization}

Potassium is necessary for stem strength, especially for cut flower production. Apply fertilizer at planting with the band 2-12 inches to the side and

1. This document is ENH885, one of a series of the Environmental Horticulture Department, Florida Cooperative Extension Service, Institute of Food and Agricultural Sciences, University of Florida. Original publication date February 23, 2003. Visit the EDIS Web Site at http://edis.ifas.ufl.edu.

2. Richard Schoellhorn, Associate Professor; Everett Emino, Professor; Erin Alvarez, Student Assistant, Environmental Horticulture Department, Institute of Food and Agricultural Science, University of Florida, Gainesville, Fl 32611.

The Institute of Food and Agricultural Sciences is an equal opportunity/affirmative action employer authorized to provide research, educational information and other services only to individuals and institutions that function without regard to race, color, sex, age, handicap, or national origin. For information on obtaining other extension publications, contact your county Cooperative Extension Service office. Florida Cooperative Extension Service/Institute of Food and Agricultural Sciences/University of Florida/Christine Taylor Waddill, Dean. 
2-6 inches below the seed for row culture. Apply side dressings as needed. For bed culture use liquid fertilizer 20-20-20 at 100-200ppm.

\section{Propagation}

Sow seeds at a soil temp of $46-50^{\circ} \mathrm{F}$ or after last freeze, or transplant from plug trays into production beds. We have had success with a three-week-old plug transplanted into well-prepared beds.

\section{Pinching Required}

None, although some branching types benefit from terminal bud removal for longer stem laterals for use in bouquets. For cultivars with a single composite flower, pinching is not recommended.

\section{Plant Growth Regulator Recommendations}

None.

\section{Photoperiod}

Cultivar dependent; most are day-neutral, and flowering is faster with shorter days. Growth during short-day seasons results in shorter stems, while growth during longer days and higher temperatures produces longer stems before flowering.

\section{Spacing}

Plant seeds 1 inch deep, 6-12 inches apart in the row with rows 18-36 inches apart for row culture. For intensive bed culture for use in cut flower bouquets 6 inches by 6 inches $(15 \mathrm{~cm})$ in winter and closer spacing in summer produces nice sized flowers on eighteen-inch or longer stems. Lower density plants per unit area result in thicker and longer stems and larger flowers.

\section{Scheduling}

Sow seeds weekly or biweekly to maintain a steady supply of flowers throughout the season. Additional information on crop scheduling based on ongoing research will be available in the future for Sunbright.

\section{Common Problems}

Overhead watering may lead to spotting on flower petals. Weed control is essential to quality cut flower production. Sunflower beetle and cucumber beetles attack foliage and flower petals. Cut worms, when present, destroy seedlings and plug transplants. Downy mildew, sclerotinia root and stalk rot, verticillium wilt, rust and powdery mildew are problematic diseases. It is generally not recommended to plant sunflowers in the same area for more than two consecutive years.

\section{Weed Control}

Weed control is essential to quality cut flower production. The following is a list of herbicides used in cut flower production. Always follow label directions when applying or using herbicides. Pre-emergence herbicides include: bensulide $\left(\right.$ Betasan $^{\circledR}$ ), dithiopyr (Dimension ${ }^{\circledR}$ ), napropamide $\left(\right.$ Devrinol $\left.^{\circledR}\right)$, oryzalin $\left(\right.$ Surflan $\left.^{\circledR}\right)$, metolachlor (Pennant ${ }^{\circledR}$ ), and trifluralin $\left(\operatorname{Treflan}^{\circledR}\right)$. Nonselective, post-emergence herbicides include: diquat $\left(\right.$ Reward $\left.^{\circledR}\right)$, glufosinate $\left(\right.$ Finale $\left.{ }^{\circledR}\right)$, glyphosate (Roundup-Pro $^{\circledR}$ ), paraquat $\left(\right.$ Gramoxone ${ }^{\circledR}$ ), and pelargonic acid $\left(\right.$ Scythe $\left.^{\circledR}\right)$. Selective, post-emergence herbicides include: clethodim $\left(\right.$ Envoy $\left.{ }^{\circledR}\right)$, fluazifop-p (Fusilade ${ }^{\circledR}$, Vantage ${ }^{\circledR}$ ).

\section{Harvest}

Harvest cut flowers when petal color is visible and well before all the petals are unfolded. Cut the stems as long as possible during cooler periods of the day and when flowers are free from dew, and place in floral preservative or acidified clean water. The use of clean buckets and cutting tools for harvesting is important.

\section{Consumer / Postharvest Information}

\section{Cut Flowers}

Strip all of the leaves except for a few at the top of the stem, re-cut the stem, store at $36-40^{\circ} \mathrm{F}$ for up to one week. Expect a 7-10 day vase life for older cultivars. The newer, pollen-free types can last up to fifteen days with proper care. Although sunflowers 
as cut flowers do not benefit from floral preservatives (fresh flower food), the addition of preservatives to prevent or reduce bacterial buildup is useful. Similarly, changing the water regularly and cleaning the vase is important to extending the post harvest life of sunflower cut flowers.

\section{Cultivars for Outdoor Cut Flower Production}

Sunbright has been grown at the UF/IFAS Specialty Cut Flower research plots successfully. Sunrich Lemon, Sunrich Orange, Soraya, and Moulin Rouge are also grown in Florida. New cultivars with potential are being introduced regularly by the major seed companies and should be trialed for use in Florida.

\section{Grower resources}

Growing For Market. Edited and published by Lynn Bycznski. Fairplains Publications, Box 3747, Lawrence, KS 66046. Phone: 785-748-0605

Sustainable Cut flower Production. An online resource of Appropriate Technology Transfer for Rural Areas (ATTRA). Contact ATTRA: PO Box 3657, Fayetteville, AR72702. Phone: 1-800-346-9140 FAX: (501) 442-9842 http://www.attra.org/attra-pub/cutflower.html

Association of Specialty Cut Flower Growers, Judy Laushman, Executive DirectorMPO Box 268, Oberlin, $\mathrm{OH} 44074$, phone 440-774-2887

http://www.ascfg.org

Helianthus.com, a web resource featuring most common cultivars and basic information

\section{References}

Armitage, A. 1993. Cut Flowers. Press, Portland, OR. 372 p.

Byczynski, L.The Flower Farmer: An Organic Grower's Guide to Raising and Selling Cut Flowers. Chelsea Green, Vermont. 207 p.

Gast, K. 1995. Production and Postharvest Evaluation of Fresh Cut Sunflower. Report of progress 751. http://www.oznet.ksu.edu/library/hort2/SRP751.PDF
Gill, S., E. Dutky, R. Balge, W. MacLachlan, and S. Klick. 1997. Producing Annual Sunflowers as Cut flowers. University of Maryland Cooperative Extension Service, Fact Sheet 686. p.1-8.

Smith, Tina, and Neal, Joseph C. 2002. Weed management for outdoor cut flowers. University of Massachusetts Extension Service. http://www.umass.edu/umext/programs/agro/ floriculture/floral_facts/cutweed.html

Starman, T., T. Cerny, and A. MacKenzie. Productivity and profitability of some field grown specialty cut flowers. HortScience. October. p. 1217-1220. 